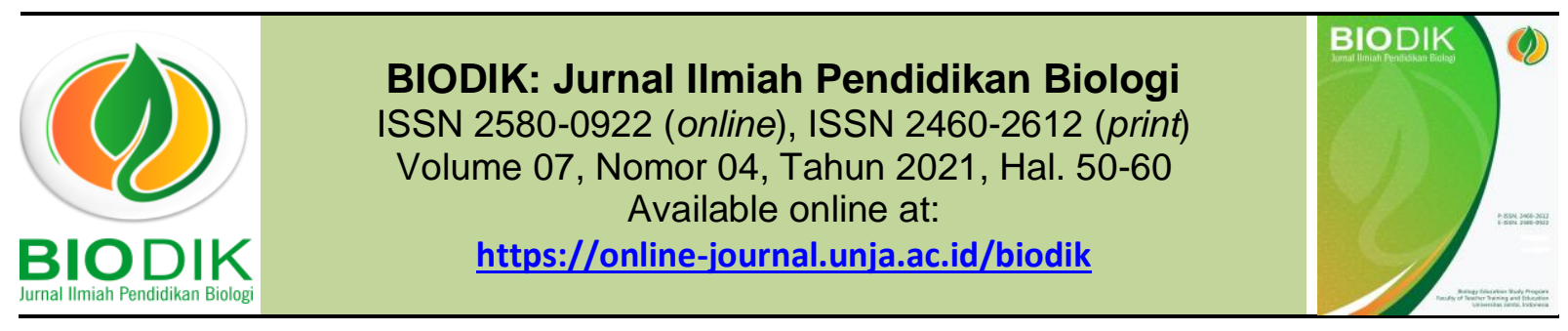

Research Article

BIODIK: Jurnal IImiah Pendidikan Biologi

ISSN 2580-0922 (online), ISSN 2460-2612 (print)

Available online at:

https://online-journal.unja.ac.id/biodik

\title{
Analisis Pelaksanaan Pembelajaran Daring di Masa Pandemi Covid-19 Pada Guru Mata pelajaran IPA di SMP Kota Jambi
}

\section{(Analysis of the Implementation of Online Learning during the Covid-19 Pandemic for Science Subject Teachers at Jambi City Junior High School)}

\author{
Ema Faorika*, Afreni Hamidah, Evita Anggereini \\ Program Magister Pendidikan IPA Universitas Jambi \\ JI. Raden Mattaher No.21, Ps. Jambi, Kota Jambi, Jambi 36133, Indonesia \\ *Corresponding Authors: emafaorika111@gmail.com
}

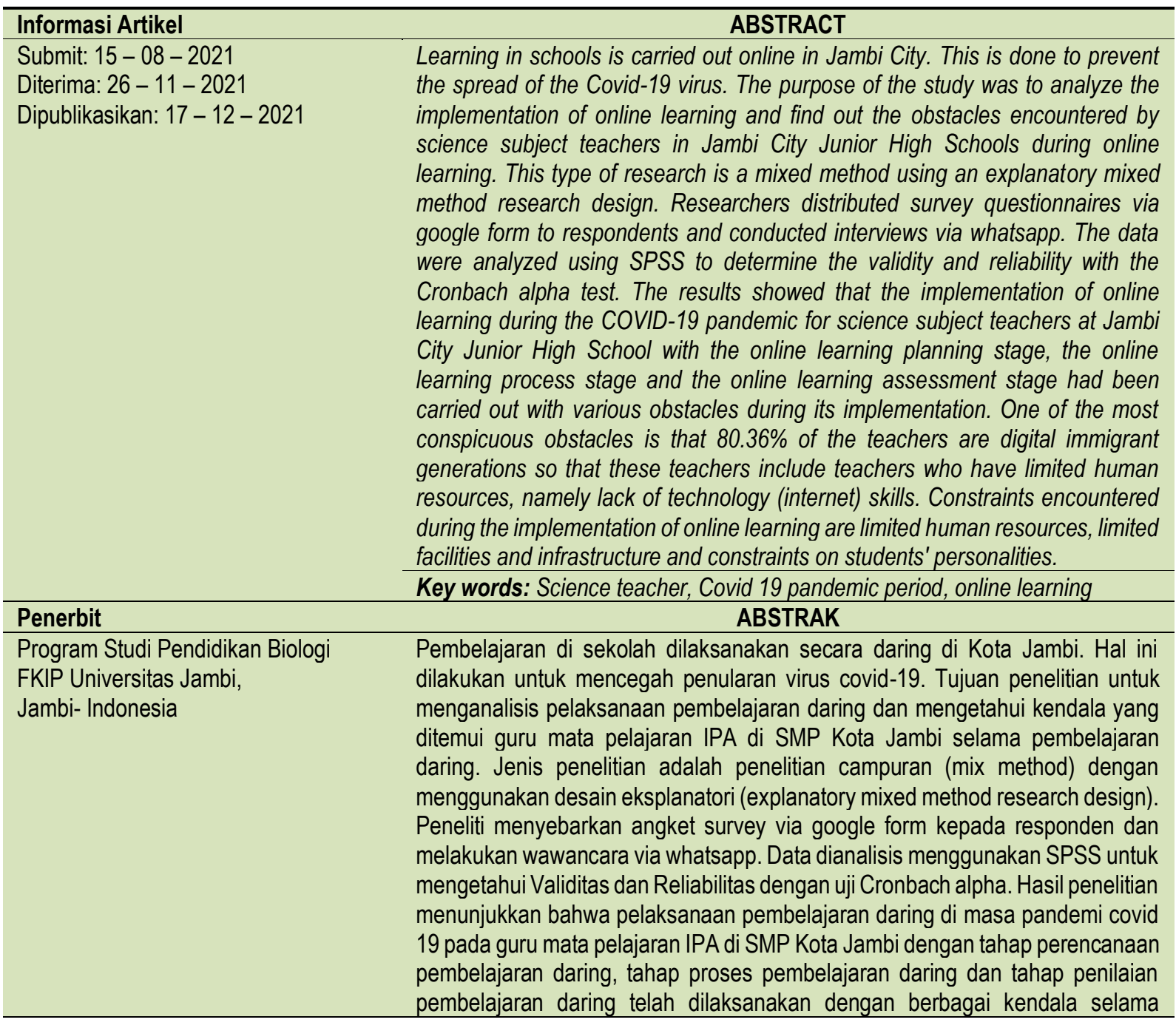


pelaksanaanya. Salah satu kendala yang paling mencolok adalah $80,36 \%$ guru tersebut merupakan generasi digital immigrant sehingga guru-guru tersebut termasuk guru yang memiliki keterbatasan sumber daya manusia yaitu kurang menguasai teknologi (internet). Kendala yang ditemui selama pelaksanaan pembelajaran daring yaitu keterbatasan sumber daya manusia, keterbatasan sarana dan prasarana dan kendala pada pribadi siswa.

Kata kunci: guru IPA, masa pandemi Covid-19, Pembelajaran daring,

\section{(i) (2) (2)}

BY NC SA

This BIODIK : Jurnal IImiah Pendidikan Biologi is licensed under a CC BY-NC-SA (Creative Commons Attribution-ShareAlike 4.0 International License)

\section{PENDAHULUAN}

Pada awal tahun 2020, dunia tengah dihebohkankan dan dibuat panik dengan kemunculan sebuah virus misterius yang dikenal dengan nama Corona Virus Disease 2019 (Covid-19). Virus ini muncul pertama kali di Kota Wuhan China pada akhir bulan Desember tahun 2019. Virus ini telah menyebar hampir ke semua negara di dunia termasuk Indonesia dalam beberapa bulan saja karena proses penularannya yang sangat cepat. Virus ini akan mengakibatkan gangguan ringan hingga berat pada sistem pernapasan, infeksi paru-paru yang berat hingga kematian. Virus ini dapat menyerang siapa saja, mulai dari bayi, anak-anak, remaja, orang dewasa, ibu hamil dan menyusui dan akan lebih sering menyerang lanjut usia karena memiliki riwayat penyakit bawaan (Hendri, 2020).

Pandemi Covid-19 telah mempengaruhi hampir semua aspek kehidupan manusia. Untuk memutus mata rantai penularan virus tersebut, pemerintah, termasuk pemerintah Indonesia, telah melakukan berbagai tindakan pembatasan. Pendidikan sekolah menengah merupakan salah satu sektor yang terkena dampak wabah tersebut. Sejauh ini, Kementerian Pendidikan dan Kebudayaan belum mengizinkan pemerintah daerah di luar kawasan zona kuning dan hijau untuk membuka sekolah. Dalam rangka mewujudkan hak siswa untuk mengakses layanan pendidikan di masa darurat penyebaran Corona Virus Disease (Covid-19), proses pembelajaran dilakukan dengan menerapkan belajar dari rumah (BDR) seperti yang tertuang dalam Surat Edaran Kemendiknas. No. 4 Tahun 2020 Kemendikbud Tentang ketentuan pelaksanaan kebijakan pendidikan pada masa darurat penyebaran Covid-19, SK Sekjen No. 15 Tahun 2020 tentang darurat Covid-19.

Berkenaan dengan penyebaran Covid-19 yang semakin meningkat maka kesehatan guru, kepala sekolah, dan seluruh warga sekolah menjadi bahan pertimbangan utama dalam pelaksanaan pembelajaran. Oleh karena itu, Menteri Pendidikan dan Kebudayaan Republik Indonesia Bapak Nadiem Makarim pada Tanggal 24 Maret 2020 mengeluarkan Surat Edaran (SE) yang berisi mengenai Pelaksanaan Kebijakan Pendidikan dalam Masa Darurat Penyebaran Covid-19. Pada tahapan kedua tentang kegiatan belajar dari rumah (BDR) dilaksanakan dengan ketentuan sebagai berikut: a) BDR melalui pembelajaran daring dilaksanakan untuk memberikan pengalaman belajar yang bermakna untuk siswa, tanpa terbebani tuntutan menuntaskan seluruh capaian kurikulum untuk kenaikan kelas maupun kelulusan; b) BDR dapat dititikberatkan dalam pendidikan kecakapan hidup seperti pandemi Covid-19; c) aktivitas dan tugas pembelajaran BDR dapat bervariasi antara siswa, sesuai minat dan kondisi masingmasing siswa termasuk mempertimbangkan kesenjangan akses/fasilitas BDR; d) bukti atau produk aktivitas hasil BDR diberi umpan balik yang bersifat kualitatif dan berguna dari guru, tanpa diharuskan memberi skor/nilai kuantitatif (Kemendikbud, 2020). Negara berkembang seperti Indonesia, pembelajaran 
daring tidak dapat memberikan hasil yang diharapkan, karena sebagian besar siswa tidak dapat mengakses internet karena masalah teknis dan ekonomi (Adnan, 2020). Namun, meski masih banyak keterbatasan dalam proses pelaksanaannya, pembelajaran daring di rumah menjadi solusi terbaik bagi komunitas pendidikan di masa pandemi Covid-19 (Jena, 2020).

Berdasarkan hasil wawancara awal dengan beberapa guru IPA di SMP Kota Jambi secara daring menggunakan video call dan menggunakan telpon diketahui bahwa di setiap sekolah dimana guru IPA mengajar di Kota Jambi telah melaksanakan pembelajaran secara daring. Pelaksanaan pembelajaran daring di sekolah tersebut ada yang menggunakan aplikasi Whatsapp, Zoom, Google Clasroom dan Google Meet tergantung kemampuan guru masing-masing. Sebelum melaksanakan pembelajaran, guru melakukan persiapan terlebih dahulu yaitu membuat rencana pelaksanaan pembelajaran (RPP), membuat video pembelajaran sendiri atau mendownload video dari youtube lalu dibagikan kepada siswa. Selain itu, ada juga guru yang menggunakan aplikasi zoom untuk menjelaskan materi kepada siswa. Guru-guru juga mengatakan bahwa mereka mengalami kesulitan atau kendala selama belajar daring misalnya guru kesulitan dalam menggunakan aplikasi pembelajaran daring yang baru mereka kenal. Kebijakan pelaksanaan pembelajaran daring oleh pemerintah Kota Jambi dilaksanakan dari rumah hanya berlaku untuk siswa dan dilaksanakan di sekolah untuk guru. Jadi meskipun pembelajran dilaksanakan secara daring, guru harus tetap hadir di sekolah dan mengajar daring dari sekolah.

Sehubungan dengan mewabahnya Covid-19 dan diberlakukannya Surat Edaran Menteri Pendidikan dan Kebudayaan No. 4 Tahun 2020, maka pembelajaran di sekolah-sekolah baik negeri maupun swasta di Kota Jambi dilaksanakan secara daring. Sekolah yang melaksanakan pembelajaran secara daring adalah sekolah dengan zona merah, orange dan kuning sesuai dengan keputusan gugus Covid di daerah masing-masing. Oleh karena itu, peneliti tertarik untuk meneliti pelaksanaan pembelajaran daring di SMP Kota Jambi. Peneliti mengambil sampel guru mata pelajaran IPA di SMP Kota Jambi untuk disurvey karena menurut peneliti, mata pelajaran IPA sangat menarik karena berhubungan dengan alam dan kondisi lingkungan sekitar. Kota Jambi adalah salah satu wilayah yang merupakan Ibukota Provinsi Jambi yang terjangkau jaringan internet dan paling banyak terdampak Covid19. Sehingga kemungkinan guru IPA Kota Jambi dapat melaksanakan pembelajaran daring dengan efektif. Tujuan dari penelitian untuk Menganalisis pelaksanaan pembelajaran daring di masa pandemi Covid-19 pada guru mata pelajaran IPA di SMP Kota Jambi dan untuk mengetahui kendala apa saja yang ditemui guru mata pelajaran IPA di masa pandemi Covid-19 di SMP Kota Jambi.

\section{METODE PENELITIAN}

Jenis penelitian adalah penelitian campuran (mix method) dengan menggunakan desain eksplanatori (explanatory mixed method research design), yaitu suatu desain penelitian yang menggabungkan data dan metode analisis data kuantitatif dan kualitatif dimana data yang lebih diutamakan adalah data kuantitatifnya. Dalam hal ini, data kualitatif digunakan untuk mendukung data kuantitatif. Populasi dalam penelitian ini adalah seluruh Guru mata pelajaran IPA yang ada di SMP Kota Jambi yang berjumlah 170 orang guru. Sampel penelitian adalah total sampling yaitu seluruh populasi menjadi sampel. Dimana sampel yang disurvey disebut sebagai responden yang menjawab angket survey secara sukarela dan tanpa paksaan.Penelitian ini dilaksanakan pada bulan Juni sampai Agustus 2020. Adapun tempat penelitiannya adalah di SMP Kota Jambi. 
Instrumen penelitian yang digunakan yaitu Angket survey menggunakan google form dan lembar wawancara menggunakan aplikasi whatsapp. Teknik pengumpulan data menggunakan angket survey yaitu dengan menyiapkan kisi-kisi angket survey yang sudah di validasi pembimbing, membuat quisioner angket survey menggunakan google form, menyebar angket survey kepada responden uji coba dalam bentuk link kepada responden, melakukan uji validitas dan realiabilitas menggunakan SPSS versi 23 pada responden uji coba, melakukan validasi konten terhadap item soal bersama pembimbing, melakukan uji realiabilitas dengan Cronbach Alpha,menyebar angket kepada responden sebenarnya yaitu guru IPA Kota Jambi, melakukan uji reliabilitas lagi dengan Cronbach alpha, data angket survey dari google form dicopy mengunakan spareshet untuk diolah item multiple respon dan item open respon lalu diolah dalam bentuk persentase.

\section{HASIL PENELITIAN DAN PEMBAHASAN}

Hasil penelitian didapat bahwa responden yang mengisi angket survey uji coba sebanyak 22 orang responden. Hasil uji validitas angket survey uji coba pada 50 soal skala likert yaitu memiliki nilai signifikansi $<0,05$ sebanyak 45 soal yang artinya 45 soal tersebut dikatakan valid dengan nilai korelasi rtabel dengan taraf signifikansi 0,05 dan terdapat 5 soal yang tidak valid yaitu soal no. 7, 22, 39, 44 dan 47. Nilai Cronbach alpha sampel uji coba yaitu 0,974 . Selanjutnya nilai Cronbach Alpha untuk responden guru mata pelajaran IPA di SMP Kota Jambi dengan kategori reliabilitas sangat tinggi yaitu 0,961 artinya item soal dalam angket survey tersebut dapat dipercaya atau memiliki tingkat kepercayaan sangat tinggi. Dengan kata lain, angket tersebut apabila dilakukan pengulangan maka hasilnya tidak berubah.

\section{Pelaksanaan Pembelajaran Daring}

Pelaksanaan pembelajaran daring dilakukan melalui tahap tahap perencanaan pembelajaran, tahap proses pembelajaran dan tahap penilaian pembelajaran. Ketiga tahapan tersebut telah dilaksanakan oleh guru mata pelajaran IPA di SMP Kota Jambi. Hal ini sesuai dengan pendapat Dewi, dkk (2021) bahwa guru melaksanakan proses pembelajaran melalui tahap perencanaan, pelaksanaan, dan evaluasi. Data dari hasil wawancara dan angket survey dituangkan dalam bentuk tahapan perencanaan pembelajaran, proses pembelajaran dan penilaian pembelajaran serta kendala-kendala yang dihadapi selama dilaksanakannya pembelajaran daring pada tabel 9. Untuk pelaksanaan pembelajaran akan dibahas berdasarkan tahap-tahap berikut:

1. Tahap Perencanaan Pembelajaran

Hasil survey menyatakan bahwa guru mata pelajaran IPA di SMP Kota Jambi 100\% setuju untuk bekerjasama dengan wali murid dengan meminta dukungan berupa pendampingan untuk murid demi kelancaran pelaksanaan pembelajaran. Hal ini sesuai dengan hasil wawancara pada tabel 9 soal nomor 1 seluruh responden wawancara menyatakan setuju. Artinya data dari wawancara mendukung data hasil survey dan adanya triangulasi data.

Selanjutnya hasil survey menyatakan $100 \%$ setuju bahwa sebelum melaksanakan pembelajaran daring, guru perlu mendata terlebih dahulu apakah siswa memiliki HP android atau tidak, memiliki kuota internet atau tidak. Hasil survey juga senada dengan hasil temuan wawancara bahwa Setuju karena data profil siswa sangat diperlukan dan tidak semua siswa memiliki HP dan kuota internet.

Pada tahapan perencanaan pembelajaran selanjutnya, hasil survey menunjukkan $85,72 \%$ setuju sebelum dilaksanakan pembelajaran guru perlu memperkenalkan terlebih dahulu beberapa 
aplikasi yang bisa digunakan dalam pembelajaran daring kepada siswa. Hal ini sejalan dengan hasil temuan wawancara yaitu perlu supaya: (a) Siswa dapat memahami aplikasi yang digunakan. (b) Saat pembelajaran berlangsung siswa dapat mengikuti pelajaran dengan baik bersama guru. (c) Anak mengunduh aplikasi tersebut di HP nya. (d) Saat pembelajaran berlangsung siswa sudah paham dengan aplikasi yang dipakai sehingga pembelajaran dari guru dari jarak jauh dapat terlaksana. (e) Pada saat pembelajaran tidak ada kendala.

Selanjutnya hasil survey menyatakan bahwa $98,20 \%$ guru setuju sebelum melaksanakan pembelajaran daring, guru mengirimkan video tutorial cara penggunaan aplikasi pembelajaran daring kepada siswa. Hal ini senada dengan hasil temuan wawancara yaitu guru setuju gunanya agar siswa dapat: (a) Memahami dan menggunakan aplikasi yang akan digunakan agar pembelajaran berjalan lancar dan baik. (b) Mengerti penjelasan secara garis besar dari guru. (c) Memberikan pengetahuan awal.

Hasil survey berikutnya untuk tahap perencanaan yaitu 100\% guru setuju sebelum pelaksanaan pembelajaran perlu membuat grup kelas online untuk PBM daring. Hal ini sesuai dengan hasil temuan wawancara yaitu responden menjawab perlu, supaya: (a) Semua materi pembelajaran dan penilaian dapat tersampaikan. (b) Mempermudah dalam memberikan informasi dan materi. (c) Dapat berinteraksi. (d) Memperlancar proses KBM. (d) Dapat mengontrol kehadiran, mengecek langsung siswa yang mengerjakan tugas dan berdiskusi.

Berdasarkan hasil survey pada tahap perencanaan didapat pula data jawaban responden yang menyatakan sebelum proses pembelajaran dilaksanakan guru perlu melakukan kegiatan berikut:

a. Guru $100 \%$ perlu merencanakan pembelajaran dalam bentuk RPP daring yang diketahui oleh kepala sekolah. (soal angket survey no.1)

b. Guru $98,20 \%$ perlu memiliki sarana dan prasarana yang lengkap seperti HP, leptop dan jaringan internet yang bagus untuk melaksanakan pembelajaran daring. (soal angket survey no. 8)

c. Guru $92,86 \%$ membutuhkan pelatihan terlebih dahulu sebelum mengajar secara daring. (soal angket survey no.9)

d. Guru $100 \%$ perlu membaca pedoman pembelajaran daring. (soal angket survey no. 10)

e. Guru $94,65 \%$ perlu menguasai teknik mengajar daring. (soal angket survey no. 13)

f. Guru $83,92 \%$ perlu menyiapkan bahan (materi) yang akan dikirim ke siswa (soal angket survey no. 14)

g. Guru $87,50 \%$ perlu mengembangkan sendiri RPP dan 94,65\% mengembangkan RPP bersama teman sejawat berupa sintaks, link materi dan penilaian). (soal no. 15 dan 16)

h. Guru $73,22 \%$ perlu melakukan sosialisasi kepada siswa dengan mengirim peraturan dan langkah yang akan dilakukan dalam proses pembelajaran secara daring. (soal angket survey no.17)

i. Guru $75 \%$ perlu membuat live presentasi dalam pembelajaran daring (soal angket survey no.18)

j. Guru $78,57 \%$ perlu membuat video dan guru $75 \%$ perlu membuat PPT untuk dikirm ke siswa menggunakan aplikasi whatsaap grup. (soal angket survey no.20 dan 21). 
Dari data perencanaan ini akan dilanjutkan oleh guru pada tahap proses pembelajaran yang akan dibahas pada bagian tahap proses pembelajaran.

\section{Tahap Proses Pembelajaran}

Berdasarkan tabel 9 hasil temuan wawancara menunjukkan bahwa guru mata pelajaran IPA SMP di Kota Jambi telah melaksanakan tahap proses pembelajaran daring dengan menggunakan aplikasi whatsapp sebagai aplikasi yang paling banyak digunakan selama pembelajaran daring karena mudah diakses siswa. Whatsapp paling banyak digunakan diikuti zoom, google form, google classroom, dan live facebook. Hal ini senada dengan data hasil survey dimana whatsapp juga sebagai aplikasi terbanyak yang digunakan guru mata pelajaran IPA di SMP Kota Jambi selama proses pembelajaran daring.

Dalam pembelajaran berbasis daring, guru IPA yang ada di Kota Jambi kebanyakan menggunakan aplikasi whatshapp dibandingkan aplikasi lain. Menurut responden, aplikasi whatsapp mudah digunakan dan responden sudah terbiasa menggunakannya dalam kehidupan sehari-hari. Dengan menggunakan whatsapp, guru dapat memberikan arahan maupun informasi kepada siswa mengenai pelaksanaan pembelajaran daring kepada siswa. Melalui aplikasi whatsapp ini, siswa dapat mengirimkan tugas kepada guru secara personal dengan mudah. Selain itu, siswa dapat mengirim dokumen baik kepada guru maupun kepada temannya dengan cara diteruskan dengan mudah. Hal ini sesuai dengan pendapat Wildan (2019) dalam Lestari (2021) bahwa aplikasi WhatsApp mempunyai fitur yang dapat menyimpan dokumen dalam bentuk format microsoft word, pdf, excel, ataupun powerpoint. Pada kegiatan berbagi dokumen menggunakan WhatsApp akan lebih mudah dengan format tersebut. Aplikasi WhatsApp digunakan untuk meneruskan pesan sehingga memudahkan siswa yang ingin berbagi pesan dengan siswa yang lainnya. Misalnya ada siswa yang catatan materi di sekolah kurang lengkap lalu meminta bantuan kepada teman yang lain yang memiliki catatan materi lebih lengkap maka ia bisa membagikannya dengan fitur forward. Fitur ini bertujuan agar memudahkan siswa untuk mengirim maupun melanjutkan ke teman yang lain tanpa harus membuka file manager di smartphone/gawai.

Salah satu keuntungan menggunakan aplikasi whatsApp adalah dapat menggunakan fungsi voice note untuk pembelajaran daring. Dalam kegiatan ini, siswa dan guru dapat bergabung dalam grup di aplikasi WhatsApp. Guru membagikan materi kepada siswa atau hanya mempublikasikan pengumuman/pemberitahuan melalui group. Selain voice note, guru juga dapat membagikan materi berupa teks Microsoft Word atau PDF, foto, dan video.

Aplikasi whatsApp juga dapat digunakan untuk diskusi antara guru dengan siswa dan antara siswa dengan siswa lainnya. Pembelajaran ini dapat dimulai ketika guru menyerahkan topik/materi kepada siswa dalam kelompok, kemudian guru membimbing siswa untuk memecahkan masalah tersebut. Siswa juga dapat mengemukakan pendapatnya dan mencantumkan nama serta nomor kehadiran sebagai identitasnya sehingga guru dapat mengevaluasi seluruh siswa yang tergabung dalam grup. Dalam pembelajaran daring, guru harus mampu berinovasi membuat materi baru semenarik mungkin untuk disampaikan kepada siswa. Jika materi pembelajaran tidak dibuat menarik, maka siswa akan merasa bosan, dan karena tidak ada pertemuan langsung atau tatap muka antara siswa dan guru, siswa akan merasa bingung dalam memahami materi (Wildan 2019 dalam Lestari 2021).

Berdasarkan hasil survey pada tahap proses pelaksanaan pembelajaran guru setuju menggunkan video ketika memberikan materi kepada siswa (soal no. 28). Menurut peneliti, 
menggunakan video sebagai media pembelajaran akan memudahkan guru dalam menyampaikan materi sehingga lebih mudah dipahami siswa karena didalam video pembelajaran tersebut sudah terkandung penjelasan lengkap beserta soal-soal latihan yang dapat dipelajari oleh siswa.

1. Tahap Penilaian Pembelajaran Daring

Berdasarkan tabel 7 soal no. 41 hasil survey menunjukkan bahwa $76,78 \%$ setuju membuat soal online menggunakan google form. Hal ini senada dengan temuan hasil wawancara yaitu guru menyatakan perlu membuat soal online menggunakan google form dengan alasan sebagai berikut:

1. Membuat penilaian lebih efektif berupa penilaian harian $(\mathrm{PH})$, penilaian tengah semester (PTS) dan penilaian akhir semester (PAS).

2. Memudahkan melakukan penilaian terhadap hasil ujian siswa karena di dalam google form terdapat fitur untuk melakukan evaluasi (penilaian) jadi saya tidak perlu mengoreksi satu persatu jawaban siswa

3. Mudah digunakan

4. Mempermudah membuat soal dan mengoreksi

5. Supaya tidak hilang dan bisa dilihat dan digunakan jika perlu siswa mudah mengaksesnya kembali

6. Memudahkan mengecek jawaban siswa

7. Siswa lebih serius mengerjakannya dan tidak mengulur wktu pengumpulan tugas serta siswa lebih semangat karena nilainya bisa langsung dilihat

Berdasarkan hasil penelitian dapat diketahui bahwa guru IPA di Kota Jambi telah melaksanakan penilaian dalam pembelajaran daring. Bentuk penilaian terhadap siswa yang dilakukan yaitu dengan menggunakan google form. Soal-soal dikirim melalui google form, kemudian dikerjakan oleh siswa dan dikirimkan lagi kepada guru. Dengan menggunakan google formulir, guru dapat dengan mudah menilai hasil kerja siswa. Hal ini terjadi karena di dalam aplikasi google formulir tersedia fitur bentuk dan teknik penilaian.

Selanjutnya hasil temuan wawancara dengan menanyakan aplikasi apa yang guru gunakan dalam tahap penilaian selain google form didapat jawaban guru yaitu : (a) Memberikan nilai angka dan komentar masukan dan mengolah nilai dengan manual atau sendiri. (b) Menggunakan microsoft exel. (c) Manual yaitu menyuruh siswa mengirim foto lembar jawaban dikirim melalui whatapp pribadi baru dikoreksi. (d) Menilai langsung tugas siswa di clasroom. (e) Teknik penskoran dari jawaban siswa.

Guru perlu mempublikasikan hasil penilaian kepada siswa setelah nilai diolah oleh guru. Hal ini sesuai dengan hasil survey dimana $82,10 \%$ guru setuju mempublikasikan nilai kepada siswa dan hasil temuan wawancara yaitu gurupun setuju dengan alasan yaitu: (a) Siswa tahu sebatas mana penguasaan materi yang disampaikan. (b) Siswa tahu dia tuntas atau tidak dalam belajar. (c) Siswa tahu tugas dinilai guru. (d) Untuk memotivasi siswa kedepan belajar lebih semangat.

Pada tahap penilaian, guru juga melakukan remedial dan pengayaan bagi siswa. Hal ini dimaksudkan agar tujuan pembelajaran benar-benar tercapai. Dalam pengerjaan tugas oleh siswa, guru IPA di Kota Jambi juga meminta bukti foto atau video pada saat siswa mengerjakan tugas. Hal ini berguna untuk mengecek apakah siswa atau siswa benar-benar melaksanakan tugas yang diberikan. Disinilah diperlukannya kerja sama antara orang tua/wali siswa dengan guru untuk mengawasi siswa atau siswa dalam mengerjakan tugas. 


\section{Kendala Pelaksanaan Pembelajaran Daring}

Dalam pembelajaran daring, banyak kendala yang dihadapi oleh guru maupun siswa selama proses belajar mengajar berlangsung. Dari tabel 4.10 hasil survey kendala pembelajaran daring dan hasil wawancara didapatkan beberapa alasan yang menjadi kendala dalam proses pembelajaran daring diantaranya:

1. Keterbatasan sumber daya manusia dalam survey, yaitu guru kurang menguasai internet sehingga kesulitan dalam pembuat soal pembelajaran daring, guru kesulitan mengajar jarak jauh, guru capek membuat laporan daring ke dinas, guru capek menyiapkan materi tugas dan bahan ajar. Sedangkan hasil temuan wawancara yaitu guru merasa kesusahan dalam menjelaskan materimateri fisika yang seharusnya bisa dijelaskan secara langsung kepada siswa melalui tatap muka dan guru juga seharusnya bisa melihat langsung kerja siswa. Guru juga merasa kesulitan untuk menilai keterampilan siswa ketika melaksanakan praktikum IPA. Namun karena pembelajaran dilaksanakan secara daring maka hal tersebut sulit untuk dilakukan. Hasil penelitian sesuai dengan pendapat Effendi (2008) bahwa kekurangan pembelajaran daring yaitu kurangnya sumber daya manusia (SDM) untuk menguasai internet. Hasil angket survey penelitian didapatkan data $80,36 \%$ guru IPA di SMP Kota Jambi berusia $>31$ tahun yang artinya guru tersebut adalah generasi digital immigrant dan 19,64\% guru IPA di Kota Jambi berusia <31 tahun yang artinya guru tersebut adalah generasi digital natives. Responden angket survey no. 2 dan 31 termasuk ke dalam generasi digital immigrant mengatakan bahwa kendala pelaksanaan pembelajaran daring yaitu kurang menguasai teknologi dan capek menyiapkan materi dan bahan ajar. Hal ini sesuai dengan hasil penelitian Herischa (2013) dimana guru senior hanya mampu menggunakan komputer pada tingkat dasar untuk menyiapkan perangkat saja dan guru senior mampu menggunakan TIK dengan mengikuti diklat dan pembimbingan dari teman sejawat. Menurut Sulistiyanto (2017), generasi digital immigrant adalah generasi yang lahir sebelum tahun 1990. generasi ini belum mengenal komputer sehingga wajar saja mereka kurang menguasai teknologi sehingga terkendala selama pelaksanaan pembelajaran daring.

2. Keterbatasan sarana dan prasarana pada hasil survey yaitu masih ada siswa yang belum memiliki HP, tidak adanya kuota internet dan aplikasi HP tidak support. Selain itu koneksi internet yang tidak stabil juga menjadi kendala dalam proses belajar mengajar. Hal ini senada dengan hasil temuan wawancara yaitu terkendala jaringan internet, tidak memilihi HP android dan tidak memiliki kuota internet.

3. Kendala pada diri siswa dari hasil survey yaitu: siswa kurang merespon materi yang diberikan guru, siswa kurang aktif, siswa kurang memahami materi yang diberikan, siswa tidak mengumpulkan tugas dan ada juga siswa yang tidak join kelas. Hal ini senada dengan kendala dalam temuan wawancara yaitu siswa kurang serius, kurang respon dan kurang aktif mengikuti pembelajaran, pemahaman siswa kurang tepat, tugas siswa tidak semua terkumpul dan minat belajar siswa kurang.

Senada dengan Gavrilova (2006), ia mengatakan bahwa kelemahan pembelajaran daring adalah pembelajaran yang membutuhkan lebih banyak peralatan tambahan. Komputer, gadget, paket data internet dan peralatan serta persyaratan teknis lainnya menjadi kendala terutama bagi mereka yang tinggal di pedesaan dan belum terbiasa dengan proses pembelajaran daring. Selain Pendapat tersebut, menurut hasil penelitian Leidner (1993), dijelaskan bahwa kendala pembelajaran daring adalah kurangnya kedisiplinan dalam mengatur waktu dan kurangnya sumber daya manusia dalam penggunaan 
teknologi yang mendukung proses pembelajaran. Siswa yang tidak memiliki keterampilan dasar dan tingkat disiplin diri yang tinggi tidak dapat mengikuti pembelajaran daring dengan baik. Hal ini senada dengan apa yang disampaikan oleh Gavrilova (2006) bahwa kekurangan dan kendala pembelajaran daring adalah kebutuhan akan peralatan tambahan yang lebih banyak. Paket data internet menjadi kendala pada peralatan dan persyaratan teknis seperti komputer dan teknologi untuk mendukung pembelajaran daring, terutama bagi mereka yang belum terbiasa dengan proses pembelajaran daring.

Memindahkan proses pembelajaran tatap muka (offline) ke proses daring (online), tentunya memiliki kelebihan dan kekurangan tersendiri dalam proses pelaksanaannya. Dari sisi kesehatan, kebijakan ini sangat efektif menekan dan mengurangi jumlah pasien yang terpapar kasus penularan Covid-19. Dari sisi pendidikan, berbagai institusi pendidikan di Indonesia belum bisa menerapkan kebijakan ini dengan sebaik-baiknya. Masih banyak lembaga pendidikan di beberapa daerah yang memiliki keterbatasan dalam akses internet, perangkat keras (hardware) dan perangkat lunak (software). Pembiayaan pembelajaran seringkali menjadi kendala untuk memaksimalkan penggunaan aplikasi belajar daring dan ketidaksiapan dalam penggunaan aplikasi menjadi salah satu alasan kurang efektifnya pembelajaran daring. Pemindahan proses pembelajaran dari tatap muka menjadi pembelajaran daring menggunakan berbagai jenis aplikasi yang ada sekarang ini menjadikan sumber belajar siswa menjadi tidak terbatas, bahkan mereka mempunyai ruang yang jauh lebih luas dari mereka belajar di kelas. Guru sebagai pendidik perlu

memahami ini sebagai suatu keharusan dalam proses pembelajaran, namun peran guru dalam proses pengawasan di dalam proses pembelajaran dan dalam menyampaikan materi tetap harus ada. Oleh sebab itu, guru bisa menggunakan live presentasi dalam PBM daring. Guru-guru IPA di Kota Jambi sebagian besar sudah menggunakannya dalam proses pembelajaran.

Selain itu, dalam penyampaian materi pembelajaran kepada siswa, guru diminta memberikan materi dengan cara yang semenarik mungkin, sehingga memunculkan minat belajar yang tinggi dan materi pembelajaran tersampaikan dengan sempurna dan siswa mampu menyerap materi yang disampaikan dengan mudah. Salah satu media yang bisa digunakan untuk menyampaikan materi pelajaran yaitu power point dan video pembelajaran. Penggunaan power point bisa lebih memfokuskan siswa terhadap materi yang akan dipelajari, selain itu fitur-fitur yang ada didalamnya juga mampu menarik siswa agar materi tersampaikan dengan baik. Penggunaan powerpoint sebagai media pembelajaran juga memberikan wawasan pembelajaran menggunakan media yang interaktif dan menarik sehingga memberikan pembelajaran yang bersifat nyata serta menarik perhatian dan minat dari siswa.

Terkait keefektifan pembelajaran daring dibandingkan dengan tatap muka, berdasarkan hasil survey kebanyakan guru mata pelajaran IPA di SMP Kota Jambi menyatakan bahwa pembelajaran yang dilaksanakan secara daring tidak efektif yaitu $87,5 \%$, karena menurut responden banyak hal yang menghambat berlangsungnya proses belajar mengajar. Sekitar $7,1 \%$ orang responden menyatakan bahwa pembelajaran daring efektif karena daring sesuai kondisi covid-19 saat ini, dengan quota unlimited siswa dapat mengikuti pembelajaran dengan segala aplikasi, dan jika siswa dan orang tua berperan dalam pendampingan siswa. Selain itu peran orang tua dalam mengontrol siswa selama proses pembelajaran daring sangat diperlukan. Mengingat orang tua yang mengawasi anak selama berada dirumah.

Berdasarkan hasil survey bahwa dibandingkan dengan pembelajaran daring, guru-guru IPA di Kota Jambi lebih memilih pembelajaran dengan tatap muka. Alasan mereka adalah demi memutus rantai penyebaran Covid -19 maka pembelajaran secara daring mau tidak mau harus tetap dilaksanakan 
daripada tidak adanya kegiatan belajar mengajar sama sekali. Guru IPA di SMP Kota Jambi ingin sekali kembali melaksanaan pembelajaran secara tatap muka jika tidak ada pandemi. Hasil survey dapat dilihat pada gambar 1 dimana pada sumbu $x$ adalah jenis pembelajaran yang dipilih responden dan sumbu y adalah persentase responden yang memilih jenis pembelajaran. Untuk lebih jelasnya dapat dilihat pada gambar 1.

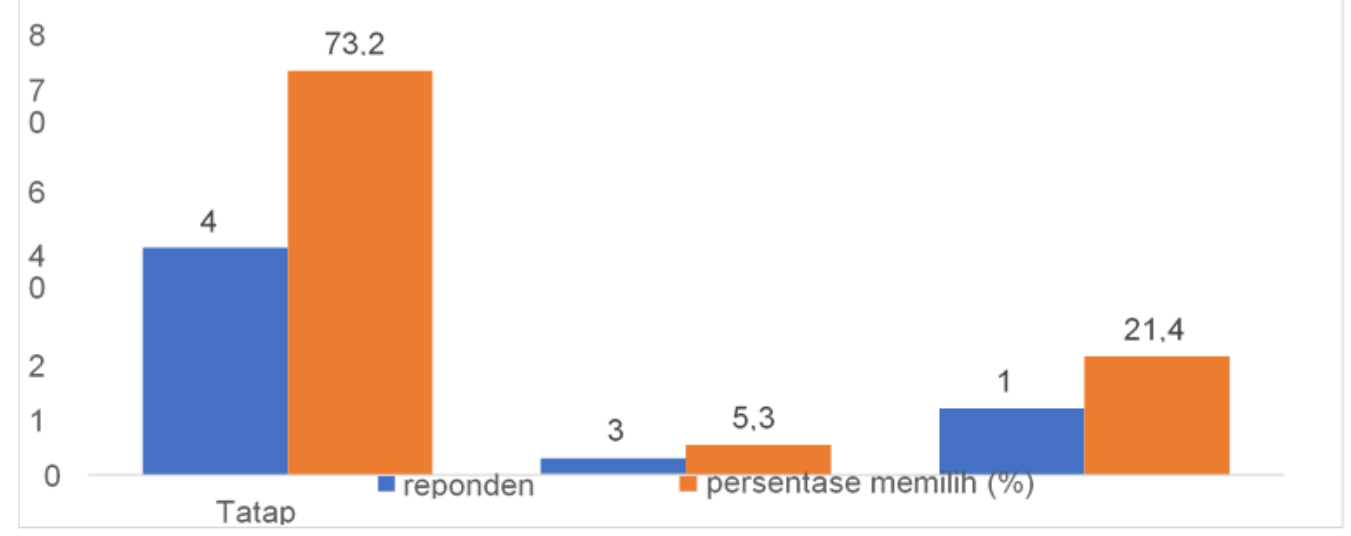

Gambar 1 Jenis Pembelajaran yang dipilih oleh Guru IPA SMP di Kota Jambi

Dari gambar 1 diperoleh bahwa guru IPA di SMP Kota Jambi lebih memilih pembelajaran dengan tatap muka dibandingkan dengan pembelajaran daring. Responden juga ada yang memilih mix yaitu gabungan antara tatap muka dan daring. Jika diurutkan dari yang terbanyak hingga yang sedikit yaitu tatap muka, mix dan daring. Sedikitnya guru yang memilih pembelajaran daring disebabkan karena guru merasa pembelajaran daring kurang efektif. Namun, meskipun demikian tidak dipungkiri bahwa pembelajaran daring juga memiliki dampak positif, diantaranya membuat siswa dan guru lebih melek teknologi. Namun dikarenakan masih banyak kekurangan di sana sini, maka pembelajaran dengan tatap muka lebih baik.

\section{SIMPULAN}

Pelaksanaan pembelajaran daring di masa pandemi covid 19 pada guru mata pelajaran IPA di SMP Kota Jambi dengan tahap perencanaan pembelajaran daring, tahap proses pembelajaran daring dan tahap penilaian pembelajaran daring telah dilaksanakan dengan berbagai kendala selama pelaksanaanya. Salah satu kendala yang paling mencolok adalah $80,36 \%$ guru tersebut merupakan generasi digital immigrant sehingga guru-guru tersebut termasuk guru yang memiliki keterbatasan sumber daya manusia yaitu kurang menguasai teknologi (internet). Kendala yang ditemui selama pelaksanaan pembelajaran daring yaitu keterbatasan sumber daya manusia, keterbatasan sarana dan prasarana dan kendala pada pribadi siswa.

\section{UCAPAN TERIMA KASIH}

Terima kasih pada Ibu Dr. Afreni Hamidah, S.Pt., M.Si ddan Ibu Dr. Evita Anggereini selaku pembimbing tesis yang telah banyak membantu dari pembuatan proposal hingga penelitian ini selesai. Ucapan yang sama peneliti sampaikan kepada bapak Kepala Dinas Pendidikan KotaJambi dan Guru IPA SMP di Kota Jambi yang telah membatu terlaksananya penelitian ini. 


\section{RUJUKAN}

Alimin, A., \& Effendi, H. (2020). Pengembangan Modul Pembelajaran Berbasis Daring Pada Mata Diklat Instalasi Penerangan Listrik Kelas XI Di Sekolah Menegah Kejuruan. Ranah Research: Journal of Multidisciplinary Research and Development, 2(4), 133-138.

Arikunto, Suharsimi. (2010). Prosedur Penelitian Suatu Pendekatan Praktik Edisi Revisi. Jakarta: Rineka Cipta.

Fatimah, D., Chan, F., \& Sofwan, M. (2021). Analisis pelaksanaan pembelajaran daring pada masa pandemi Covid-19 di sekolah dasar (Doctoral dissertation, UNIVERSITAS JAMBI).

Gavrilova. (2006). Pengertian, Karakteristik Dan Manfaat Pembelajaran Jarak Jauh (Daring). Dalam https://ejournal/eprints.uny.ac.id.v ol.5. Diakses 20 Maret 2021.

Henri. 2020. Mengenal Pasar Hewan di Wuhan, Tempat berkembangnya Virus Corona. https://www.liputan6.com/lifestyle/read/4165006/mengenal- pasar-hewan-di-wuhan-tempatberkembangnya-virus-corona diakses tanggal 11 Juli 2020.

Jena, P. K. (2020). Impact of pandemic COVID-19 on education in India. International journal of current research (IJCR), 12.

Kemendikbud. (2020). Surat Edaran Pelaksanaan Kebijakan Pendidikan dalam Masa darurat Covid-19. Jakarta: Kemendikbud.

Kemendikbud. (2020). Pedoman Penyelenggaraan Belajar dari Rumah, Jakarta.Diakses, 29 Mei 2020.

Leidner. (1993). Kendala Pembelajaran Jarak Jauh Atau Daring. Dalam http://jurnal/repository.unpas.ac.i d/12994/4/BAB\%2011.vol5.pdf. Diakses 3 Mei 2021.

Lestari, F. A. P. (2021). Pengaruh Penggunaan Google Clasroom Dan Whatsapp Group Dalam Pembelajaran Terhadap Hasil Belajar Mahasiswa Di Era Pandemi Covid 19. In SINASIS (Seminar Nasional Sains) (Vol. 2, No. 1).

Miarso dan Yusuf Hadi. (2008). Menyemai TeknologiPendidikan. Jakarta: Kencana Prenada Media Group.

Putria, H., Maula, L. H., \& Uswatun, D. A. (2020). Analisis Proses Pembelajaran dalam Jaringan (DARING) Masa Pandemi Covid-19 Pada Guru Sekolah Dasar. JurnalBasicedu, 4(4),864https://scholar.google.co.id/scholar?q=jurnal+analisis+pembelajaran+daring\&hl=id\&as sdt=0\&as vis=1\&oi=scholart\#d=gs_cit\&u= $\% 2 F$ scholar $\% 3 F q \% 3 D i n f o \% 3 A X y Y w W n o G a B g J \% 3 \mathrm{~A}$ scholar.google.com\%2F\%26output\%3Dcite\%26scirp\%3D2\%26hl\%3Did diakses 11 Juli 2020.

Sudjono, Anas dkk. (2009). Cara Mudah Menggunakan dan Memaknai Path Analysis (Analisis Jalur). Bandung: Alfabeta.

Sugiyono. 2012. Metode Penelitian Kuantitatif Kualitatif dan R\&D. Bandung: Alfabeta.

Sulistyanto, Agung. (2017). Generasi Digital Natives dan Digital Immigrants. https://www.codepolitan.com/generasi-digital-natives-dan-digital-immigrants-58f838b3ba9e0 diakses 20 september 2021. 